\title{
Implicações da arte contemporânea na escola: conflitos e estranhamentos de uma cultura do belo
}

\author{
Kelly Bianca Clifford \\ VALENÇA
}

\section{Resumo}

A maneira como artefatos influenciam e são influenciados pela cultura é fator recorrente na contemporaneidade. Imagens e obras de arte integram esse arcabouço ideológico. Educar neste contexto é um dos desafios do ensino de arte. A arte contemporânea apresenta um potencial para considerar a subjetividade de alunos e, conseqüentemente, favorecer um ensino crítico e inclusivo. Este trabalho investiga o modo como seis alunos, futuros professores - três mulheres e três homens - do curso de Licenciatura em Artes Visuais da Faculdade de Artes Visuais da Universidade Federal de Goiás, compreendem e se relacionam com imagens da arte contemporânea como objeto de ensino.

Palavras-chave: Arte Contemporânea, Ensino de Arte, Cultura Visual. 


\section{Kelly Bianca Clifford Valença}

Mestre em Cultura Visual pela Universidade Federal de Goiás (UFG), Especialista em Arteterapia pela Faculdade Mauá de Brasília e Licenciada em Desenho e Plástica pela Universidade Federal de Pernambuco (UFPE). Atualmente é professora do Projeto Arte Educação da Fundação Jaime Câmara de Goiânia-GO. 